\title{
The Cultivation of Legal Faith In Undergraduate Education of Law -Taking the Legal Education of Sichuan Agricultural University as an Example
}

\author{
Qi Haiyan ${ }^{1, a}$ \\ ${ }^{1}$ School of Law, Sichuan Agricultural University, \\ Ya'an, P.R.China, 625001 \\ a1643076273@qq.com
}

\begin{abstract}
The establishment of a socialist country under the rule of law, it is in line with the socialist modernization construction of statecraft. The country want to Implement the rule of law that must meet two conditions, first, the country should established a good legal system, second, the seriously comply with the legal system of the people. If Country want people to comply with the law better, it need to cultivate people's belief in lawl. The undergraduate education of law, as the main position of cultivating legal talents, need to strengthen the cultivation of students' legal faith, need to set up the student's confidence in the law firm and the deep emotions of law. The university must to cultivate students to use the power of faith to guide legal practice, the students have to strive to become a good law talents.
\end{abstract}

Key words : law; education of law ; legal faith

\section{INTRODUCTION}

Faith, is refers to the people are very convincing and respect a religion or creed, and people use it as the guidelines of the action. And legal belief, is people identity law faithfully, comply with the law firmly, and enforce the law seriously." Pullman, a Jurists, once said that "the law must be faith, otherwise it will be useless. People must believe that the

law is not only a kind of rules, it contains

the value of fairness and justice, and It represents the people's faith to seek a better life

continuously.

Law and morality are social rules. But the law is the lowest moral. The law itself contains a lot of value philosophy of the moral system, such as justice and equality. So the law must like moral is rooted in the hearts of people, get people to follow and respect. The supremacy and authority of the law, it depend on the sanctity of the people's feelings of the law, and it also need the public to believe the law sincerely, as a kind of feelings, which similar to the religious. Only in this kind of belief, this kind of respect and trust of love, people for the law, will be inspired. And it will be to establish and maintain the orientation and authority of law really. This is to start the people the power of the spirit, to belief in law, and people believe that the law will bring the justice, the safe social environment and the better life to people.

In the national strategy of the rule of law, it not only needs the legal talent, but also need the legal talent who has legal faith. The people ,who make the law as faith, will be to comply with the law authority and defend the dignity of the law and believe in the power of the law. Under the impetus of the talent, who has the faith of law, will be to ensure the practice and the promotion of law, and it also to encourage people to obey the law and create a better life, when people has the respect for the law nobly.

2. The present situation and the reasons of the lack of legal faith - make the Sichuan agricultural university as an example.

\subsection{The present situation to cultivate the legal faith}

The Sichuan agricultural university, opened the key undergraduate course of law, it recruit 120 people each year. The teaching plan of law ,which included 16 main subjects of law, involves the theory of law and legal practice and so on each link, but did not cultivate 
specialized courses of law belief, even no related courses. Is not only the Sichuan agricultural university, but also the most of the other university haven't the courses about legal faith. Legal faith exists only in occasional mention when the teachers in teaching .University, as the law talent training base, transports a large number of legal talent to social every year. But because in the university education is often neglected the cultivation of legal belief, excessive emphasis on legal pragmatism, The Students only take the law as a tool to make a living and earn money, they are not belief in law really.

The Law is supreme, it is not only a kind of rules, but also the ideal of people's mind and the patron saint of justice. However, the reality is, the university hasn't attaches great importance to the cultivation of legal belief, and the teachers don't know how to cultivate legal faith, so the students have no ideal of the law faith. This is the current situation of legal faith in the undergraduate education of law.

\subsection{The cause of lack of legal faith}

Lack of legal faith, it is caused by various reasons, First of all, affected by historical reasons in China, the man thought has a deep history basis, Between the rights and law, people often think that power above the law, rule of man is higher than the rule of law. This makes people lose confidence and the identity of the law, also they lack of respect and trust for the law naturally. China's legal construction has just started, it is still a long way to go to change a few thousand years of traditional. In reality, there are many drawbacks of legal system, There will be a lot of problems, when people to implement the law, so Sometimes, people will be disappointed in law and conflict the law, This leads to people do not believe that the law, legal faith is difficult to establish.

Second, in the realistic society. People pursue legal pragmatism, namely the role of law in solving practical problems, and the function of the law of the constraints of the real life, while ignoring the law to guide people's heart. the law major is always the popular major of University. Because people believe that studying law can bring a good job, high income, such as a law student graduation can be judges, prosecutors and lawyers and other professional, These occupations have a high social status in China and the objective of income. So many people just the law as a tool of making money, as a means of making a living, Rather than take the law as faith.

Finally, from the foundation of Chinese modern education of law, its goal is to cultivate legal talents, who suited to the socialist rule of law needs. Therefore, on the training mode, it also focuses on the legal subject practicality and practical, but ignore the role of law faith to the students. From the point of curriculum design of law in Sichuan agricultural university, It is not a course about legal faith. Socialist legal education with Marxism as the guiding ideology, it believe that everything is objective and everything is material, .More than half a century after the education of Marxism, in fact, we are a generation without faith.

Sometimes, the author will ask students what is faith in teaching. But almost no one has the answer. these are caused by lack of legal faith education.

\section{The necessity of cultivating legal faith}

\subsection{Cultivating legal faith helps to strengthen the students confidence in the law}

In just a few years, China's legal construction has made great achievement, it formed the basic perfect law system, and it established a team of professional legal talents. But the legal system still has a lot of loopholes, and there are a lot of difficulties and problems in the law enforcement process, In some cases, which the negative influence is very big, hurt the public recognition and confidence of law. In the process of teaching, the teacher will also involves a lot of cases, to analyze a lot of the insufficient and defect of the legal system, This tend to reinforce the students' doubts about the present situation of the rule of law. So, the teacher must make students to believe that the law firmly, Let them to believe that the law is the embodiment of kindness and justice, Let them to believe that the rule of law is bound to be more and more perfect. To strengthen the cultivation of the students' legal faith, actually is to inspire students' inner desire to 
use the power of belief to learn law better.

\subsection{Cultivating legal belief helps to carry out the legal education}

The power of spirit is great, if the students have the law faith, they believe to what they learned is the embodiment of kindness and justice, Then they will be more active in learning. In the process of law education, if the teachers pay attention to the cultivation of student's legal belief, and combining the legal practice, it must can achieve very good effect.

\subsection{Cultivating legal belief helps to the national to form the rule of law thought,}

To Implement the rule of law, need the public's respect, recognition, and accept to the law. If there is no public respect, recognition and acceptance of law, The law will lose stability, and It would be no authority. Law are like a dead letter,

The theory of the rule of law would be for the rule of man. The social public faith in law, is the important guarantee of the rule of law spirit formation, It deeply reflects the connotation and spiritual temperament of the rule of law. On the other hand, the connotation and spiritual temperament of the rule of law. Which is the expression of the whole social mental and emotion. is the law faith. efore, in this sense, to cultivate the public legal faith, which is beneficial to the formation of the whole society the spirit of the rule of law, will be helpful for the construction of the rule of law society.

\section{The way of the cultivating of the legal faith in law education,}

\subsection{To specialize courses of law belief in the undergraduate major of law}

In traditional law undergraduate program, can increase a course of legal faith, which has 2 credits, can be offered in the first term. Legal faith as a specialized course, when it has the credit requirement, it's status will be improved greatly and it's function will be strengthened. The university to set up one course of legal faith, it also can let the student fully to realize the importance of legal faith. The students will known it is necessary to have the legal faith to study the law they will take the law as heart admiration and constraint to go to the pursuit of progress. The Students, who have legal faith, will not break the law, because these students have bond from the heart. On the basis of this, they will have more independent and standardize of law, and they will have more respect for the authority of the law, when engaged in the legal profession. In the end, he will use the force of law to constraints of others, to persuade others to fully respect and abide by the laws, common to maintain the dignity of the law. So, the university must be specialize the courses of law faith in the first semester, to cultivate the students' legal belief. Students to study the course of law faith, which be specialized in the first semester, as Marxism philosophy course.

4.2 To strengthen the understanding of the college teachers about the legal belief

Teachers themselves must have the legal belief, so they can be able to cultivate the students' legal faith. In the undergraduate education of law at present, teachers are the masters of the classroom. The students mainly rely on the teacher's teaching to learn the knowledge of law, So, for students, the teacher is very important. To cultivate the students' legal belief, the teacher must belief in law at first, they must to believe the rule of law what they teach, and to respect the knowledge of law what they teach And to recognize the kind of legal thought what they understand, In this case, they can put the power of legal faith to students. Law teacher should pay attention to their own understanding of law belief. They should read relevant books and materials in normal times, and understand the connotation of legal faith, to believe in the power of faith is huge .The university Can also training the legal belief of teachers, the teachers can communicate with each other, put their own understanding of the legal faith to students in their classes.

\subsection{To strengthen the infiltration of law faith in the various legal disciplines}

The cultivation of legal belief, not happen overnight, nor by set up the course to complete. Through to strengthen the infiltration of law faith in the legal 
disciplines, make the each course have the support by law faith, to make the law discipline be sublime and beautiful. If want to strengthen the infiltration of law faith in the various legal disciplines, firstly, the teacher of each law discipline must has law faith, and they must to realize the importance of law faith to law teaching. Secondly, To increase of law belief in special chapters appropriately in the various legal disciplines, Such as judges, prosecutors, law, etc., you can set up legal faith chapter of judges and prosecutors.

\section{Conclusion}

Through several years of teaching practice of law, in Sichuan agricultural university, The author deeply realize the importance of legal faith, Also realize that terrible, if the lack of legal faith in the education of law, Our undergraduate law education to develop main force of law in legal system construction of the future. They respect and admiration of law is relate to the extent and processes of the whole legal system. So, the university must join the legal faith of course in the education of law as soon as possible, to make up for the inadequacy of the current program. Law is a kind of faith, only in this kind of faith, people trust and respect of love will be stimulating, the supremacy and the supreme authority of law can also to be able to truly establish and maintain. This is to start the people the power of the spirit, to believe in law, that the legal faith is sure to bring people to justice and safe social environment, and the law faith must also can bring people a better life.

\section{References}

[1]. Ernst, H. Patent Information for Strategic Technology Management[J]. World Patent Information, 2003, 25(3):230-245

[2]. Aristotle: \"politics\", Beijing commercial press, 1965, 199

[3]. Berman.. Law and religion. Sanlian bookstore. 1991,254 